$\begin{array}{llll}\text { MANAS Sosyal Araștırmalar Dergisi } & 2019 \quad 2019 & \text { Cilt: } 8 & \text { Ek Sayı: } 1 \\ \text { MANAS Journal of Social Studies } & \text { S: } 1 & 2\end{array}$

\author{
Atıfta Bulunmak İçin / Cite This Paper: Çağıran Kendirli, H., Kendirli, S. ve Kısacık, H. (2019). \\ "The Frauds and Errors in Auditing: A Case Study in Çorum Area", \\ Manas Sosyal Araştırmalar Dergisi, 8 (Ek Sayı 1): 1055-1069
}

Geliş Tarihi / Received Date: 12.07.2018 Kabul Tarihi / Accepted Date: 04.01.2019

Araştırma Makalesi

\title{
THE FRAUDS AND ERRORS IN AUDITING: A CASE STUDY IN ÇORUM AREA*
}

\author{
Dr. Öğr. Üyesi Hülya ÇAĞIRAN KENDİRLİ \\ Hitit Üniversitesi, İktisadi ve İdari Bilimler Fakültesi \\ hulyacagirankendirli@hitit.edu.tr \\ ORCID ID: 0000-0001-7381-306X \\ Prof. Dr. Selçuk KENDÍRLI \\ Hitit Üniversitesi, İktisadi ve İdari Bilimler Fakültesi \\ selcukkendirli@hitit.edu.tr \\ ORCID ID: 0000-0002-1526-0337 \\ Öğr. Gör. Harun KISACIK \\ Hitit Üniversitesi, Sosyal Bilimler Meslek Yüksekokulu \\ harunkisacik@hitit.edu.tr \\ ORCID ID: 0000-0002-3282-4472
}

\begin{abstract}
In this study, we tried to explain the meaning of errors and frauds in accounting. Firstly, technical information was explained about the concept of auditing and accounting audit. Then, mistakes and frauds were examined in accounting. At the end of the study, a questionnaire was prepared and took the evaluated and the opinions of the Chartered Accountant (CA) and the Certified Public Accountant (CPA), which are working in Çorum. As a result of the questionnaire survey and face-to-face interviews conducted with 134 members, a great majority of the members of the profession expressed their opinion that their colleagues did not comply with professional ethics. In addition, according to result of the study, we explored about that professional members are making some frauds and mistakes in the area.
\end{abstract}

Keywords: Audit, Error, Fraud.

\section{DENETIMDE HILE VE HATALAR: ÇORUM BÖLGESINDE BİR ÇALIŞMA}

$\ddot{O} z$

Bu çalışmada, muhasebe sistemindeki hata ve hilelerin anlamı açıklanmaya çalışılmıştır. İlk olarak, muhasebe ve denetim süreci ile ilgili olarak teknik bilgi verilmiştir. Daha sonra, muhasebedeki hata ve hile kavramları açıklanmaya çalışıımıştır. Çalışmanın sonunda, bir anket çalışması hazırlanmış ve Çorum merkezinde faaliyetlerini sürdüren Yeminli Mali Müşavir ve Serbest Muhasebeci mali Müşavirler üzerinde uygulanmış, onların bu konudaki değerlendirmeleri ve fikirleri alınmıștır. 134 meslek mensubu ile yüz yüze yapılan anket araştırmasının sonuçlarına göre, meslek mensuplarının çoğunluğuna göre, meslek mensupları mesleki etiğe sahip değildirler. Ek olarak, çalışmadan elde edilen sonuçlara göre, meslek mensuplarının, çalışma sahasında bazı hata ve hileleri yaptıkları tespit edilmiştir.

Anahtar Kelimeler: Denetim, Hata, Hile.

\footnotetext{
${ }^{*}$ This study is the corrected version of the presented in the 4th International Conference on Economic Sciences and Business Administration "Looking for New Horizons: The Circular Economy" 24-25 November 2017 Bucharest/Romania.
} 


\section{INTRODUCTION}

Accounting is a kind of system that collects information systematically which are the data of events and transactions of the financial nature for the enterprise in terms of money, which is processed by recording, classification, and analysis, taking into account the needs and aims of the persons concerned with the enterprise and providing the results in reports (Büyükmirza, 2010: 27). The first function of the account is to recording to events. But that alone is not enough. The results obtained from the recording must be processed into meaningful information. A large number of people are interested in this information because of the spread of the capital, especially due to the public offering operations in the developing markets. Administrators use reliable, impartial, relevant, and consistent information that is generated by business owners, business owners, lenders, the government, and public sector accountants. The party receiving this information can make better decisions than the others. Deliberate or unintentional mistakes and deceptions in the process of recording and reporting reduce the reputation of the accountancy profession and cause damage to various individuals or institutions, especially the state. For this reason, Chartered Accountant (CA), Certified Public Accountants (CPA), and their employees are required to comply with both ethical and accounting principles.

In this study we just tried to describe that frauds and mistakes in accounting. A questionnaire on the study was conducted and tried to take opinions of the Chartered Accountant (CA) and the Certified Public Accountant (CPA) operating in Çorum concerning mistakes and frauds in accounting.

\section{AUDIT CONCEPT AND AUDIT IN ACCOUNTING}

The fundamental of the word of "audire" from Latin language and it means "hearing and listening carefully'. Inspection comes to the point of examining, inspecting, and controlling whether a job is done in accordance with the correct and method about accounting records (Duman, 2008: 11).

Auditing can also be defined as a systematic process of collecting and evaluating evidence objectively in order to investigate the degree of conformity between the assertions on economic activities and events and the accepted criteria and to communicate the results to the relevant users (Erdoğan, 2005: 1).

Accounting audit can be defined as the process of collecting and evaluating evidence made by an independent expert in order to investigate the degree of conformity of an economic unit or the information of the turnover with predetermined criteria (Bozkurt, 2006: 23). Accounting audit can also be defined as a systematic review that summarizes findings 
based on work carried out on records, documents, and other evidence that forms the basis of these tables in order to determine whether a company's financial statements are organized in accordance with generally accepted accounting principles or other accounting system required by the legal status of the company (Kaval, 2003: 25).

\section{ERRORS AND FRAUDS IN ACCOUNTING}

In the Turkish Dictionary published by Turkish Language Institution, it is making description of error that wrong made unwillingly and unintentionally, or it described the error that is lapse or flawed (Güvenç, 2009: 20).

Accounting errors can describe which is caused by forgetfulness, carelessness, or ignorance, is not an intentional mistake made in accounting, records, and accounts (Duman, 2008: 147). It can also be defined as activities and behaviors that do not conform to accounting principles, rules, and principles of accounting mistakes made in enterprises. Persons do not knowingly or willingly do so in their own interests about this mistakes or errors. Errors and mistakes can stem from ignorance and negligence. However, accounting mistakes made unintentionally can harm businesses as well as fraud and corruption activities (Ertürk, 2010: 5).

When we look at the literature studies in general, it can be seen that the words "error" and "fraud" are often used together in the same sentence. This approach can cause both of the words error and fraud to be perceived as unethical behavior. Whilst in reality accounting for errors and frauds, behaviors that do not comply with accounting principles and rules come to mind, both words have different meanings as concepts (Zeytin, 2007: 85).

The error often refers to mistakes made unintentionally (Çıtak, 2007: 22). The main difference between fraud and error is whether or not there is intention. There are no intentions in faults; it comes with ignorance, carelessness, and negligence. Fraud occurs as a movement based on profit. It is to ensure that the person or persons who conduct the fraud benefit if they are not entitled to it, themselves or others. In other words, those who make mistakes are harming one another, but they do not have their own interests. However, those who commit fraud harm the others and are also willing to benefit themselves (Dumanoğlu, 2005: 349).

Certified fraud, with its short name ACFE (Association of Certified Fraud Examiners), published a report in 2010 entitled "Professional Fraud and Abuse". They described fraud that as an unfair advantage in that an employee intentionally improperly uses or seizes resources and assets of the employer (Arens et al., 2006: 314). 


\section{LITERATURE REVIEW}

Baspinar's (2006) published his article named "Responsibility of the Auditor for Corruption and Misconduct in Financial Statement Inspections", and he reached the conclusion that audit may play a deterrent role for error and fraud, but the auditor should not be held responsible for the prevention of error and fraud.

Erol (2008), in the article entitled "Expectations from Audit against Corruption (Mistakes and Frauds) in Businesses", has reached the conclusion that most of the corruption in businesses arises from the preparation or concealment of incomplete or fraudulent financial reporting.

In its article entitled "Internal Audit and Deficiency-Excess Relation to Firms", Ondes reached the result that internal control constitutes the first step in preventing actions that are inconsistent with fraud, error, laws, and regulations in an enterprise and is essentially a responsibility of the management.

Aytekin et al. (2015) published their article named "The Approaches of Practitioners towards Error and Accusations of Fraud and Fraud Indicators: The Case of Balikesir Province", and they suggests that female professionals are more likely to meet with fraud indicators and that the level of participation of judges regarding errors and fraud differ as the level of education increases, have reached the conclusion that their perception is weak.

Bayraktaroğlu (2016), in his article titled "An Investigation of the Role of Effective Internal Auditing in the Prevention of Accounting Errors and Frauds in the Enterprise", has reached the result that an effective internal audit has a positive effect of reducing the possible false and fraudulent accounting practices.

\section{ERROR AND FRAUDS IN ACCOUNTING AND A SURVEY APPLICATION TO THE SOCIETY OF PROFESSIONAL ACCOUNTANTS}

\subsection{Aim of the Research}

In the survey, it was sought to obtain opinions of the Certified Public Accountant (CPA) and the Chartered Accountant (CA) operating in the province of Çorum regarding the errors and frauds under supervision.

\subsection{Research Method}

The method of the survey is a questionnaire and the questionnaire that is held is about the professionals who are working in Çorum province center. Information on the number of members of the profession was requested by face-to-face with Çorum Chamber of Certified Public Accountants. There are 396 members registered in the room, separate of the members 
are; 291 of them are in the center, 192 of them are actively working in accounting offices, and 18 of them are women and 168 of them are men. In addition, there are 4 Chartered Accountants (CA) in Çorum province center.

As a sample mass, 4 Chartered Accountants (CA) and 192 Certified Public Accountants (CPA) located in Çorum province center were determined from the room records. All the accounting departments interviewed in Çorum, some were not able to participate in the survey due to the intensity of their work, some left after filling in the questionnaire and were taken back, and a large number of face-to-face surveys were conducted. At least, survey has been offered to 134 members in the area.

As a result of face-to-face interviews, some information has been obtained that does not reflect both professional experience and collectivity. According to the data obtained from the analytical result, it has been estimated that within the scope of the survey study, at least 128 professions must be reached with a margin of error of $5 \%$ and a $95 \%$ confidence interval. In the $98 \%$ confidence interval, this number reaches to 141 professions. In the scope of the study, a total of 134 questionnaires (134/192 (70\%)) were made.

\subsection{Hypothesis of the Research}

The hypothesis of the research is as follows:

$\mathrm{H} 1=$ There is a relationship between the profession's title, tax practices, and tax rates. According to this hypothesis, as the titles of the members of the profession differ, errors and frauds are different. In other words, error and fraud tendencies of Chartered Accountants are less than that of Certified Public Accountants.

$\mathrm{H} 2$ = There is a significant difference in the retrospective operations in the computerized accounting program with the duration of professional members' activities. With this hypothesis, as the seniority level (in years) of members of the profession increases, errors and frauds tend to increase in retrospective transactions in accounting programs.

$\mathrm{H} 3$ = There is a significant difference in the retrospective operations in the computerized accounting program with the training of professional members. With this hypothesis, as the level of education of professional members' increases, errors and frauds tend to increase in retrospective transactions in accounting programs.

$\mathrm{H} 4$ = There is a meaningful difference in the training of professional members, inefficiency in supervision, and effectiveness in errors and frauds. With this hypothesis, it is argued that insufficiencies and insufficiencies of controls increase the tendency to make error and fraud. 


\subsection{Reliability Analysis}

Reliability analysis: reliability is related to the fact that measurements cannot produce consistent and balanced results (Avci, 2008: 135). In other words, reliability analysis is used to test whether data expressing the purpose of collecting data on the units constituting the sample in any way and the constituents of the measurement tool are consistent among themselves. Participants' testimonials, which form the instrument of measurement, test whether all the expressions directed to the participant measure the same (Ural and Kilic, 2005: 258).

The reliability of the proposals generated in the study was calculated using the Alfa coefficient for testing. The reliability of the tests performed in the literature is given below (Zeytin, 2007: 116).

$0.00<$ alpha $<0.40$, the scale is not reliable,

$0.40<$ alpha $<0.60$, the scale has low reliability,

$0.60<$ alpha $<0.80$, the scale is highly reliable,

$0.80<$ alpha $<1.00$, the scale is highly reliable.

As a result of the reliability test, the Cronbach alpha value was found to be 0.671 , which allows the questions in the questionnaire to be asked to explain whether they are homogeneous or whether they constitute a whole to question. The result of the evaluation of the alpha coefficient according to the evaluation criteria applied suggests that the scale is quite reliable.

\subsection{Research Findings and Evaluation of Results}

\subsubsection{Assessment of the Demographic Data of Corum Province Accounting}

\section{Professional Members}

Within the scope of the study, 134 questionnaires were applied from the Certified Public Accountants (CPA) and Chartered Accountants (CA) in Çorum. The demographic data obtained as a result of the questionnaire survey are given below.

4 persons (3\%) are Chartered Accountant (CPM), 130 persons (97\%) are Certified Public Accountant (SMMM). According to gender distribution, it is seen that among the professionals working in Çorum, the majority of men are in the accounting profession. Among the professionals working in Çorum, the proportion of males is $91.8 \%$ and the proportion of females is $8.2 \%$. When the age distribution of the members of the profession was examined, 24 persons $(17,9 \%)$ are between 28 -35 years, 51 persons $(36,1 \%)$ between 3643 years, 29 persons $(21,6 \%)$ between $44-51$ years, and 30 persons over 52 years old $(22.4 \%)$. There are 20-27 year-olds in the survey questionnaires, but this malpractice has not marked 
any professional members. This shows that the activity of opening the accounting office in the accounting profession in Corum province is realized after 28 years of age.

When the working period of the members of the profession is examined, 12 persons (9\%) who perform the accountancy profession between 0-5 years, 30 persons $(22.4 \%)$ who perform the accountancy professions are worked between 6-10 years, 26 persons who perform the accountancy profession between 11-15 years (19.4\%), 17 persons (12.7\%) who are engaged in accountancy profession for 16-20 years, 49 persons (36.5\%) who are accounting professionals for 21 years and above. Here is the demographic information about the Certified Public Accountants who are working in the province of Corum. Their opinions are presented in the following table.

Table 1. Evaluation of Accounting Errors and Frauds Opinions of Çorum Occupants Members

\begin{tabular}{|c|c|c|}
\hline Causes of Accounting Errors & Number of Persons & $\%$ Of distribution \\
\hline Ignorance & 30 & $\% 22,4$ \\
\hline Inexperience & 12 & $\% 9$ \\
\hline Neglect & 15 & $\% 11,2$ \\
\hline Carelessness & 64 & $\% 47,8$ \\
\hline \multirow[t]{2}{*}{ Other } & 13 & $\% 9,6$ \\
\hline & Total & $\% 100$ \\
\hline Most Common Accounting Errors & Number of Persons & $\%$ Of distribution \\
\hline Math mistakes & 13 & $\% 9,7$ \\
\hline Registration errors & 69 & $\% 51,5$ \\
\hline Transmission errors & 6 & $\% 4,4$ \\
\hline Forgotten and repetition & 36 & $\% 26,9$ \\
\hline \multirow[t]{2}{*}{ Balance sheet errors } & 10 & $\% 7,5$ \\
\hline & Total $\quad 134$ & $\% 100$ \\
\hline Most Encountered Accounting Frauds & Number of Persons & $\%$ Of distribution \\
\hline Intentional mistakes & 12 & $\% 9$ \\
\hline Record before or after & 66 & $\% 49,3$ \\
\hline Fitting accounts & 7 & $\% 5,2$ \\
\hline Document fraud & 27 & $\% 20,1$ \\
\hline Masking of the balance sheet & 22 & $\% 16,4$ \\
\hline & Total & $\% 100$ \\
\hline
\end{tabular}

When Table 1 is examined, in the question of "What is the most important cause of accounting mistakes?", the Chartered Accountant (CA) and the Certified Public Accountant (CPA) gave the answer like that. 30 people (22.4\%) said from "ignorance" and 12 people (9\%) answered the question "inexperienced", 15 people (11.2\%) answered "negligence", 64 people $(47.8 \%)$ gave the answer "carelessness", and 13 people $(9.7 \%)$ gave another reply. As it can be seen in Table 1, most of the professional members consider the most important reason for accounting mistakes $(47.8 \%)$ to be carelessness or $(22.4 \%)$ ignorance. 
Directed by Chartered Accountant (CA) and Certified Public Accountant (CPA), "Which type of accounting mistake do you meet the most?" for inquiries from professionals 13 people (9.7\%) math mistakes, 69 people $(51.5 \%)$ recording mistakes, 6 people $(4.4 \%)$ transport mistakes, 36 people $(26.9 \%)$ forgotten and repetition, 10 people $(7.5 \%)$ he gave the answer to the balance sheet mistakes. As seen in Table 1, most of the members of the professions (51.5\%) indicated registration errors and $(26.9 \%)$ had forgotten and repetition options.

Directed to question to the Chartered Accountant (CA) and Certified Public Accountant (CPA) that "Which type of accounting family do you most often encounter?" and answered from them like this: 12 (9\%) of their opinions were intentional errors, 66 people's answers (49.3\%) registered before or after their time, 7 people's opinion (5.2\%) fitting accounts, 27 of them answered (\% 20,1) document fraud, 22 people (16.4\%) gave the answer to the questionnaire that masking the balance sheet. As can be seen in Table 2, the most frequent answer is $(49.3 \%)$ registration before or after the time.

Table 2 shows the opinions of the members of the profession who participated in the study, indicating the possibility of error and frauds.

Table 2. Opinions of Professional Members about Error and Fraud Risks

\begin{tabular}{|c|c|c|c|c|c|c|}
\hline & $\begin{array}{l}\text { Definitely } \\
\text { yes } \mathrm{n} / \%\end{array}$ & Yes n/\% & $\begin{array}{c}\text { No Comment } \\
\mathrm{n} / \%\end{array}$ & No $\mathrm{n} / \%$ & $\begin{array}{l}\text { Definitely } \\
\text { No n } / \%\end{array}$ & Total \\
\hline $\begin{array}{l}\text { Do You Have Backward } \\
\text { Transactions on Your Computer? }\end{array}$ & $26 / \% 19,4$ & $47 / \% 35,1$ & $7 / \% 5,2$ & $42 / \% 31,3$ & $12 / \% 9$ & $134 / \% 100$ \\
\hline $\begin{array}{l}\text { Impact of Job Density and Tax } \\
\text { Applications to the Mistake }\end{array}$ & $40 / \% 29,9$ & $62 / \% 62,3$ & $1 / \% 0,7$ & $25 / \% 18,6$ & $6 / \% 4,5$ & $134 / \% 100$ \\
\hline $\begin{array}{l}\text { The Impact of Tax } \\
\text { Applications and Tax Rates } \\
\text { To the Errors and Frauds }\end{array}$ & $30 / \% 22,4$ & $59 / \% 44$ & $7 / \% 5,2$ & $36 / \% 26,9$ & $2 / \% 1,5$ & $134 / \% 100$ \\
\hline $\begin{array}{l}\text { The Impact off Insufficient } \\
\text { Audit to Error and Frauds }\end{array}$ & $24 / \% 17,9$ & $81 / \% 60,5$ & $2 / \% 1,5$ & $24 / \% 17,9$ & $3 / \% 2,2$ & $134 / \% 100$ \\
\hline $\begin{array}{l}\text { Do You Benefit From the Tax } \\
\text { Code Voids? }\end{array}$ & $0 / \% 0$ & $51 / \% 38,1$ & $0 / \% 0$ & $83 / \% 61,9$ & $0 / \% 0$ & $134 / \% 100$ \\
\hline
\end{tabular}

We asked the professions the question "Do you have backtracked transactions in your computerized accounting program?". The answer separated like this: 26 people (19.4\%) were definitely yes, 47 people (35.1\%) were yes, 7 people (5.2\%) had no idea, and 42 people $(31.3 \%)$ he certainly gave no answer. One of the professionals said that "It is not possible to say no if you thought about the circulation of the commercial documents between the taxpayers. Because of this reason we have to make a registration and make some correction for the past. However, it would be suitable a restriction such as the periodical registrations made 3 months backwards for the correction with my opinion." When Table 2 is examined, it is found that most of the professionals (54.5\%) are retrospective in computerized accounting program. 
Directed to members of the profession the question of "Does the job density and tax practices compel you to make mistakes?". 40\% (29,9\%) of professions answered were definitely yes, 62 (46,3\%) were yes, $1(0,7 \%)$ had no idea, $25(18,6 \%)$ were not, $6(4 \% 5)$ has certainly given no answer. Table 2 shows that a large proportion of the professionals $(76.2 \%)$ think that work intensity and tax practices are inaccurate. In face-to-face interviews, members of the profession recently reported that the state had been overloaded with work.

The question of "Are tax applications and tax rates effective in mistakes and tricks" asked to the professional members. 30 members (22.4\%) answered definitely yes, and 59 (44\%) answered yes. 7 people (5.2\%) had no idea, 36 people (26.9\%) answered no, and 2 people (1.5\%) answered absolutely no. As it is seen in Table 2, most of the professional accountants (66.4\%) thought that tax applications and tax rates are effective in error and frauds.

We asked the question "Is the supervision inadequate and effective in the mistakes?" to the professionals. 24 people (17.9\%) answered absolutely yes, 81 people $(60.5 \%)$ answered yes, 2 people (1.5\%) had no idea, 24 people (17.9\%) answered no, and 3 people $(2.2 \%)$ gave the answer absolutely no. When Table 2 is examined, it can be seen that most of the professionals $(78.4 \%)$ who participated in the study are inadequate in the inspection and they think that they are effective in errors and frauds. It is a fact that inadequate supervision firms are going to cheat.

When Table 2 is examined, it is seen that $38.1 \%$ of the professions declare that they benefit from the gaps in tax laws. It is a more efficient method of reaching the goal by pretending it is a mistake and performing open transactions on both sides, while dealing with bigger crimes in different forms. It is too late or not possible at all because of the lack of auditing. A profession has declared that "it is natural to benefit from the advantages of the law in the name of avoiding tax, and it is natural to make use of the taxes that are not imposed and the gaps in the tax laws."

\subsubsection{Evaluation of Accounting Failure and Frauds for Members of Occupation in}

\section{Corum Province}

The errors and frauds of the professional accountants' opinions are shown in Table 3.

Table 3. The Opinions of Errors and Frauds for Çorum Occupation Members

\begin{tabular}{llllllc}
\hline & $\begin{array}{c}\text { Definitely } \\
\text { yes n/\% }\end{array}$ & Yes n/\% & $\begin{array}{c}\text { No Comment } \\
\mathrm{n} / \%\end{array}$ & $\begin{array}{c}\text { No n/\% } \\
\text { No n/\% }\end{array}$ & $\begin{array}{c}\text { Definitely } \\
\text { Notal }\end{array}$ \\
\hline $\begin{array}{l}\text { Level of Competence of } \\
\text { Audits }\end{array}$ & $0 / \% 0$ & $20 / \% 14,9$ & $1 / \% 0,7$ & $89 / \% 66,5$ & $24 / \% 17,9$ & $134 / \% 100$ \\
\hline $\begin{array}{l}\text { Accountants' Information on } \\
\text { Auditing }\end{array}$ & $13 / \% 9,7$ & $58 / \% 43,3$ & $5 / \% 3,7$ & $51 / \% 38,1$ & $7 / \% 5,2$ & $134 / \% 100$ \\
\hline $\begin{array}{l}\text { Fulfilling Accountant's Audit } \\
\text { Function }\end{array}$ & $6 / \% 4,5$ & $57 / \% 42,5$ & $4 / \% 3$ & $57 / \% 42,5$ & $10 / \% 7,5$ & $134 / \% 100$ \\
\hline $\begin{array}{l}\text { Accountants' Appropriate } \\
\text { Behavior }\end{array}$ & $53 / \% 39,6$ & $62 / \% 46,3$ & $5 / \% 3,7$ & $11 / \% 8,2$ & $3 / \% 2,2$ & $134 / \% 100$ \\
\hline
\end{tabular}




\begin{tabular}{lcccccc}
\hline $\begin{array}{l}\text { Relations to Professional } \\
\text { Ethics of Colleagues }\end{array}$ & $30 / \% 22,4$ & $47 / \% 35,1$ & $25 / \% 18,6$ & $23 / \% 17,2$ & $9 / \% 6,7$ & $134 / \% 100$ \\
\hline $\begin{array}{l}\text { Failure of taxpayers due to } \\
\text { delay of information }\end{array}$ & $44 / \% 32,8$ & $66 / \% 49,3$ & $3 / \% 2,2$ & $15 / \% 11,2$ & $6 / \% 4,5$ & $134 / \% 100$ \\
\hline $\begin{array}{l}\text { Freely Determining } \\
\text { Bookkeeping Fee }\end{array}$ & $32 / \% 23,9$ & $22 / \% 16,4$ & $2 / \% 1,5$ & $34 / \% 25,4$ & $44 / \% 32,8$ & $134 / \% 100$ \\
\hline $\begin{array}{l}\text { Updating Professionals } \\
\text { Information }\end{array}$ & $37 / \% 27,6$ & $61 / \% 45,5$ & $5 / \% 3,8$ & $20 / \% 14,9$ & $11 / \% 8,2$ & $134 / \% 100$ \\
\hline $\begin{array}{l}\text { Criminal Practice for Self- } \\
\text { Refraining }\end{array}$ & $20 / \% 14,9$ & $54 / \% 40,3$ & $13 / \% 9,7$ & $30 / \% 22,4$ & $17 / \% 12,7$ & $134 / \% 100$ \\
\hline $\begin{array}{l}\text { Punishment in Unethical } \\
\text { Behaviors }\end{array}$ & $21 / \% 15,7$ & $41 / \% 30,6$ & $24 / \% 17,9$ & $27 / \% 20,1$ & $21 / \% 15,7$ & $134 / \% 100$ \\
\hline
\end{tabular}

As seen in Table 3, in Turkey, especially in Çorum, the adequacy level of accounting audits is rather low compared to Çorum professionals. We asked the question that "Is the level of audit about accounting sufficient or not in Turkey?". They answered no. The majority of the members of the profession $(84.4 \%)$ gave no answer to the question.

As can be seen in Table 3, we asked the question "Do you have enough knowledge about auditors?" The participant answered like that: 13 people $(9.7 \%)$ answered definitely yes, 58 people $(43.3 \%)$ answered yes, 5 people $(3.7 \%)$ had no idea, and 51 people $(38.1 \%)$ answered no. And 7 people (5.2\%) gave answer to definitely no.

We asked the participants the question "Are you accountants performing the audit function?". They answered like: 6 people (4.5\%) answered definitely yes, 57 people (42.5\%) answered yes, 4 people (3\%) had no idea, 57 people (42.5\%) gave the anwer no, and 10 people (7.5\%) answered absolutely no. When Table 3 is examined, it is understood that half of the participants believe their knowledge is enough about auditing and the others do not.

When Table 3 is examined, a large part of the professionals (85.9\%) think that accountants are in compliance with laws and professional regulations.

We asked to think about their opinions with question "There are those in my circles who are in motion to think that they do not comply with professional ethics" to the appliers. 9 people $(6.7 \%)$ definitely did not participate in this opinion, and 23 people $(17.2 \%)$ did not participate to this opinion. 25 people $(18.6 \%)$ declared that they have no idea. 30 people (22.4\%) answered definitely participate and 47 people $(35.1 \%)$ answered participate to this judgment. As seen in Table 3, slightly more than half of the professionals (57.5\%) think that their colleagues do not conform to professional ethics. In face-to-face interviews, some members of the profession have declared that some of their colleagues have received all kinds of requests from taxpayers in order to win new customers or to protect existing customers.

It is taking some failure to deliver the accounting information and documents to the profession not on time. Members of the profession were asked to think about the idea that "accounting information is not delivered in due time by taxpayers, so that it can be 
erroneously processed". A great majority of the members of the profession (82.1\%) stated that they agreed with this opinion.

The bookkeeping fee of the members of the profession is determined by the Çorum chamber of accountants. 54 persons (40.3\%) of the professions agree that bookkeeping fees can be set freely outside the room, while 78 persons (58.2\%) do not agree that bookkeeping fees can be set freely outside the room. In the face-to-face interviews, some of the members of the profession stated that they set a base price for the bookkeeping fee of the room and that professional members can adjust the price provided that they do not fall below this base price. Some members of the profession also think that the free bookkeeping of fees other than the room can lead to unfair competition.

A large proportion of professionals $(73.1 \%)$ are professionals who constantly update themselves and their knowledge, while some (23.1\%) do not. In the face-to-face interviews, some members of the profession think that members of the profession cannot stay in the profession if they do not follow the legislation and laws, that is, they do not update their knowledge constantly.

Members of the profession were asked to think about the idea that "Professional members should be subject to legal sanctions when they cannot renew themselves". They gave unsuitable answers about this punishment because of main law orders. They said that professionals who cannot renew themselves within the competitive conditions are already punished by withdrawing themselves from the business area. As it is declared in Table 3, professionals cannot perform their profession in the full sense when they cannot renew themselves and they are deleted from the market, which is the greatest punishment.

Members of the professions were asked to think about their opinion of "Members of the profession are being punished with sufficient sanctions in unethical conduct". 21 people (15.7\%) participated strictly, 41 persons (30.6\%) participated, 24 people (17.9\%) had no idea about this subject, and 21 people $(20.1 \%)$ have absolutely disagreed and 27 participants do not agree with this topic.

\subsubsection{Result of the Hypothesis Tests}

Four basic hypotheses and hypotheses developed under the model of the study were tested by Chi-square analysis method. The results are in the following table: 
Table 4. Result of Hypothesis of Accounting Failure and Frauds for Members of Occupation in Corum Province

\begin{tabular}{|c|c|c|c|c|c|}
\hline HYPTHESIS & & Value & df & $\mathbf{P}$ & Result \\
\hline $\mathrm{H} 1=$ There is a meaningful difference between the & Chi-Square Test & 5,095 & 4 & 0,278 & \\
\hline $\begin{array}{l}\text { titles of professional members, tax practices and tax } \\
\text { rates on errors and frauds }\end{array}$ & $\begin{array}{l}\text { Chi-Square Relation } \\
\text { Coefficient }\end{array}$ & 5,182 & 4 & 0,269 & - \\
\hline $\begin{array}{l}\mathrm{H} 2=\text { There is a significant difference in the } \\
\text { retrospective operations in the computerized }\end{array}$ & Chi-Square Test & $\begin{array}{c}14,08 \\
0\end{array}$ & 16 & $\begin{array}{c}0,59 \\
3\end{array}$ & \\
\hline $\begin{array}{l}\text { accounting program with the duration of } \\
\text { professional members' activities. }\end{array}$ & $\begin{array}{l}\text { Chi-Square Relation } \\
\text { Coefficient }\end{array}$ & $\begin{array}{c}14,70 \\
8\end{array}$ & 16 & $\begin{array}{c}0,54 \\
6\end{array}$ & \\
\hline $\begin{array}{l}\mathrm{H} 3=\text { There is a significant difference in the } \\
\text { retrospective operations in the computerized }\end{array}$ & Chi-Square Test & $\begin{array}{c}24,99 \\
1\end{array}$ & 16 & $\begin{array}{c}0,07 \\
0\end{array}$ & \\
\hline $\begin{array}{l}\text { accounting program with the training of } \\
\text { professional members. }\end{array}$ & $\begin{array}{l}\text { Chi-Square Relation } \\
\text { Coefficient }\end{array}$ & $\begin{array}{c}24,39 \\
4\end{array}$ & 16 & $\begin{array}{c}0,08 \\
1\end{array}$ & \\
\hline $\mathrm{H} 4=$ There is a meaningful difference in the & Chi-Square Test & $\begin{array}{c}27,27 \\
3\end{array}$ & 16 & $\begin{array}{c}0,03 \\
9\end{array}$ & + \\
\hline supervision and effectiveness in errors and frauds. & $\begin{array}{l}\text { Chi-Square Relation } \\
\text { Coefficient }\end{array}$ & $\begin{array}{c}19,24 \\
7\end{array}$ & 16 & $\begin{array}{c}0,25 \\
6\end{array}$ & \\
\hline
\end{tabular}

When examining Table 4, hypotheses were tested at a significance level of 0.05 .

When examining the first hypothesis of the study, the HO hypothesis was rejected according to the significance level of 0.05 , and the H1 hypothesis was accepted. That means that, according to the research, there are no significant differences in the titles of professions, tax practices, and tax rates on errors and frauds.

When the research hypothesis of the second was examined, the H0 hypothesis was rejected according to the significance level of 0.05 , and the $\mathrm{H} 1$ hypothesis was accepted. That is meaning according to research, there is no significant difference in the retrospective operations in the computerized accounting program with the duration of the members of the profession.

When the third research hypothesis was examined, the H0 hypothesis was rejected according to the significance level of 0.05 , and the $\mathrm{H} 1$ hypothesis was accepted. That is meaning according to research, there is no significant difference in the retrospective processing of the computerized accounting program with the training of members of the profession.

When examining the fourth hypothesis of the study, the H1 hypothesis was rejected and the $\mathrm{HO}$ hypothesis was accepted according to the significance level of 0.05 . That is meaning according to research, there is a significant difference in the effectiveness of the members of the profession with their training, inadequacy of control, and mistakes and tricks.

\section{RESULT AND EVALUATION}

Accounting is a scientific discipline that enables transactions related to money, the inevitable element of life, to be carried out and the results presented to third participants. The information obtained after the fulfilment of the functions of accounting, the function of producing information, is not only itself; at the same time, it interests to third participants 
also. The most important participant is not only the state, but also many people or organizations such as businesses, business owners, banks, credit institutions, and investors can be mentioned with this information. Since the information generated by the accountant is directly influenced to economic decisions, information must be qualified. the accounting information must be reliable, unbiased, relevant, and consistent. At the same time, this is also a part of the accountability concept of social responsibility.

Errors and frauds that arise due to the human element constitute a serious obstacle to the achievement of the specified objectives of the enterprises. While the error is an unintended mistake, fraud consists of deliberate mistakes made to provide unfair advantage.

It is discovered by the questionnaire research on accounting professionals in Çorum, those errors and frauds are intensely present.

According to the research, Çorum professionals' majority (51.5\%) give the answer that there is registration error for the question of "Which type of accounting mistake do you meet the most?" Registration mistake means that an operation is recorded with mixed account names without any other intent. This error can result from ignorance and carelessness.

The research has revealed that the majority of professionals (49.3\%) answered the question "Which accountancy company do you meet the most?" with the answer registration before or after the time. In face-to-face interviews, some of the members of the profession defend the view that taxpayers are not bringing the documents in due time and this is the main reason for delivering.

It is the desire of problem is pressure of the taxpayers to the accountants, especially those who worry that the accountants are cheating. This is an obvious example of the fact that $48.5 \%$ of them are required to be shown higher than their profits. In the same way, $59 \%$ of the respondents were asked to reduce their tax base by increasing their expenditures or reducing their income. However, $38.1 \%$ of the accountants try to make use of the tax loopholes; $44.8 \%$ say that fraud can be applied due to high tax rates and inflation.

It has been determined that the members of the profession give different answers according to their education situation in the question "Is the supervision inadequate, is it effective in mistakes and frauds?" This difference is seen between the graduates of General High School and Trade Vocational High School. Those who graduated from the Vocational School of Commerce tend to participate less. This confirms the hypothesis that "H4 = the training of professionals, there is a significant difference in the effectiveness of insufficiently inspecting errors and tricks". 
In order to prevent mistakes made in accounting, members of the profession must continuously improve themselves and encouraged the staff they employ to be continuously trained. At the same time, errors can be reduced by checking the operations after the operation is finished. Accounting frauds could be blocked with ethics education and supervision of the professionals of accounting. Professional members should be continuously trained and supervised in ethics. However, it is not enough for the prevention of accounting frauds with training and supervision for professional members. It has been discovered in the research that taxpayers want to be sanctioned to professions for the result of their recording or general results. For preventing accounting frauds, it should also be required for taxpayers to be trained and supervised.

\section{REFERENCES}

Akgül, A. and Çevik, O. 2003. Istatistiksel Analiz Teknikleri, Ankara: Emek Ofset.

Albrecht, W. Steve. 2003. Fraud Examination. Ohio: Thomson South Western.

Arens, A. et al. 2006. Auditing and Assurance Services: An Integrated Approach, Boston: Pearson Prentice Hall.

Avc1, N. 2008. Konaklama İşletmelerinde Örgütsel Öğrenme, Işs Tutumları ve Örgütsel Sapma Arasındaki İlişkinin Analizi, İzmir: Dokuz Eylül University, Social Sciences Institute, Doctoral Thesis.

Aytekin, S. et al.. 2015. "Uygulamacıların Muhasebede Hata Ve Hileler İle Hile Belirteçlerine Yönelik Yaklaşımları: Balıkesir İli Örneği”, Muhasebe ve Denetime Bakıș, S:1, pp. 69-89.

Başpınar, A. 2006. "Mali Tablo Denetimlerinde Yolsuzluk ve Hataya İlişkin Denetçinin Sorumluluğu", Mali Pusula, S: 16, pp. 94-109.

Bayraktar, A. 2007. Türkiye'de Muhasebe Hileleri Tarihi, Edirne: Trakya University, Social Sciences Institute, Graduate Thesis.

Bayraktaroğlu, H. 2016. "İşletmelerde Muhasebe Hata Ve Hilelerinin Önlenmesinde Etkin İç Denetimin Rolü Ve Önemi Üzerine Bir Alan Araștırması", Muhasebe Bilim Dünyası Dergisi, S. 18,pp. 185-214.

Bozkurt, N. 2006. Muhasebe Denetimi, İstanbul: Alfa Yayınlar1.

Büyükmirza, K. 2010. Maliyet ve Yönetim Muhasebesi, Ankara: Gazi Kitabevi.

Çıtak, N. 2007. Hileli Mali Raporlamada Yaratıcı Muhasebe ve Bir Uygulama, Istanbul: Marmara University, Social Sciences Institute, Doctoral Thesis.

Duman, Ö. 2008. Muhasebe Denetimi ve Raporlama, Ankara: Tesmer Yayınları.

Dumanoğlu, S. 2005. "Hata ve Hile Ayrımı: Hile Denetimi", Marmara University İ.İ.B.F. Dergisi, S. 1, pp. 347-358.

Erdoğan, M. 2005. Denetim, Ankara: Maliye ve Hukuk Yayınları.

Erol, M. 2008. "İsletmelerde Yaşanan Yolsuzluklara (Hata ve Hileler) Karşı Denetimden Beklentiler", Süleyman Demirel Üniversitesi İktisadi ve İdari Bilimler Fakültesi Dergisi, S.1, pp. 229-237.

Ertürk, A. 2010. İşletmelerde Hata ve Hileyi Önlemede İç Kontrol Sisteminin Etkililiği ve Bir Uygulama, İstanbul: Marmara University, Social Sciences Institute, Graduate Thesis.

Güvenç, Z. 2009. Termal Turizm İșletmelerinde Hata ve Hilelerin Önlenmesinde Belge Sisteminin Önemi ve Bir Uygulama, Çanakkale: Çanakkale Onsekiz Mart University, Social Sciences Institute, Graduate Thesis.

Hatunoğlu, Z. et al.. 2012. İ Kontrolün Muhasebe Sistemindeki Hata ve Hilelerin Önlenmesindeki Rolü Üzerine Bir Alana Çalışması, Mustafa Kemal Üniversitesi Sosyal Bilimler Enstitüsü Dergisi, C. 9, S. 20, pp. 169-189.

Kandemir, C. 2010. Muhasebe Hilelerinin Ortaya Çıkarllmasında ve Önlenmesinde Bağımsız Denetimin Rolü ve Bağımsız Denetçinin Sorumluluğu, Adana: Çukurova University, Social Sciences Institute, Doctoral Thesis.

Kaval, H. (2003), Muhasebe Denetimi, Ankara, Akademik Denetim Danışmanlık ve Yeminli Mali Müşavirlik A.Ş.

Öndeş, T. 2009. "Firmalarda İç Denetim ve Noksanlık-Fazlalık İlişkisi”", Atatürk Üniversitesi İktisadi ve İdari Bilimler Dergisi, S. 2, pp. 15-27.

Özbirecikli, M, 2006. "Bağımsız Denetçinin Müşteri Firmanın Yolsuzluk Eylemi Karşısındaki Tutumu: Şirket Yolsuzluk Vakaları ve Yasal Düzenlemeler Çerçevesinde Bir Inceleme", Muhasebe Denetime Bakış Dergisi, Y. 5, S. 18.

Sheskin, J. D. 2000. "Handbook of Parametric and Nonparametric Statistical Procedures", Chapman \& Hall/CRC, pp. 595-681.

Sürmen, Y. 2010. Muhasebe-1, Trabzon: Celepler Matbaacıllk. 
Türedi, H. and Alıcı, Ü. 2014. “Mali Raporlama Hilelerinin Tespit Ve Önlenmesinde İç Kontrol Yapısının Önemi”, Finansal Araştırmalar ve Çalışmalar Dergisi, S. 11, ss. 119-133.

Ural, A. and Kılıç, İ. 2005. Bilimsel Araştırma Süreci ve SPSS ile Veri Analizi, Ankara: Detay Yayıncılık.

Üstündağ, G. 2005. Bazı Parametrik Olmayan İstatistiksel Yöntemlerin Incelenmesi, Adana: Çukurova Üniversitesi Fen Bilimleri Enstitüsü, Yüksek Lisans Tezi.

Yılmaz, Y. and Yılmaz, Y. 2005. "Parametrik Olmayan Testlerin Pazarlama Alanındaki Araştırmalarda Kullanımı: 1995-2002 Arası Yazın Taraması”, Dokuz Eylül Üniversitesi Sosyal Bilimler Enstitüsü Dergisi, S. 3, ss. 177-199.

Zeytin, M., 2007.Bă̆ımsız Muhasebe Meslek Mensuplarını Hata ve Etik Dışı Davranışlara Yönlendiren Faktörler, Kütahya: Dumlupınar University, Social Sciences Institute, Graduate Thesis. 